University of Nebraska - Lincoln

DigitalCommons@University of Nebraska - Lincoln

1980

\title{
Reflectorized soybean canopy in relation to transpiration and herbicide phytotoxicity
}

\author{
S.N. Ogbuehi \\ J.R.C. Leavitt \\ James R. Brandle \\ University of Nebraska - Lincoln, jbrandle1@unl.edu
}

Follow this and additional works at: https://digitalcommons.unl.edu/natrespapers

Part of the Natural Resources and Conservation Commons, Natural Resources Management and Policy Commons, and the Other Environmental Sciences Commons

Ogbuehi, S.N.; Leavitt, J.R.C.; and Brandle, James R., "Reflectorized soybean canopy in relation to transpiration and herbicide phytotoxicity" (1980). Papers in Natural Resources. 1088.

https://digitalcommons.unl.edu/natrespapers/1088

This Article is brought to you for free and open access by the Natural Resources, School of at DigitalCommons@University of Nebraska - Lincoln. It has been accepted for inclusion in Papers in Natural Resources by an authorized administrator of DigitalCommons@University of Nebraska - Lincoln. 


\title{
Reflectorized Soybean Canopy in Relation to Transpiration and Herbicide Phytotoxicity ${ }^{1}$
}

\author{
S. N. Ogbuehi, J. R. C. Leavitt and J. R. Brandle \\ Institute of Agriculture and Natural Resources, University of Nebraska, \\ Lincoln, NE 68583
}

The reflective properties of a vegetative canopy influence its energy balance. Increased albedo results in reduction of net radiation impinging on the plant. This reduction of net radiation often lowers both the leaf temperature and transpiration. Kaolinite, cilite, and other inert, white materlals have been used to increase the albedo of plant canopies (ABOU-KHALED et a1. 1970, DORAISWAMY and ROSENBERG 1974). ABOU-KHALED et al. (1970) working with orange (C1trus sinensis var. Valencla), rubber plant (F1cus elastica), and bean (Phaseolus vulgaris) found that a coating of kaolinite reduced leaf temperature 3 to $4 \mathrm{C}$, reduced transpiration 22 to $28 \%$, and increased water use efficiency, particularly under conditions of high light intensity and high atmospheric evaporative demand. Simflar results are contained in several published reports on this subject (BARADAS at al. 1976, FUCHS et al. 1976, LEMEUR and ROSENBERG 1976, STANHILL et a1. 1976).

The phytotoxic action of soll applied herblcides depends on their uptake by roots and translocation within the plant to the site of toxic action. The above processes are closely assoclated with the rate of transpiration (MINSHALL 1954, OORSCHOT 1970). The environmental variables that influence rate of transpiration (11ght intensity, humidity, and temperature) are also known to influence the phytotoxicity of root-absorbed herbicides ( ASHTON 1965, OORSCHOT 1965 and 1970).

This study was undertaken to evaluate the abllity of kaolinite as a reflectant to reduce soybean [Glycine max (L.) Merrill 'Elf'] transpiration and the phytotoxictty of atrazine [2-chloro-4(ethylamino)-6-(isopropylamino)-s-triazine] and plcloram (4-amino-3,5,6trichloropicolintc acid).

\section{MATERIALS AND METHODS}

Six seeds of soybean were sown on October 10, 1979 in $15 \mathrm{~cm}$ diameter black plastic pots contalning $420 \mathrm{~g}$ of Sharpsburg silty clay loam (Typic Argiudolls). Seedlings were thinned to four per pot after the expansion of the unifollate leaves. Pots were maintained in a heated greenhouse with natural sunlight plus supple-

1Published as Paper No. 6006, Journal Serles, Nebraska Agricultural Experiment Station. 
mental light from 1000 watt metal-halide lamps (Day Brite Lighting Division, Emerson Electric Co., U.S.A.) providing total irradiance of $116 \mathrm{Wm}^{-2}$ at the top of the plants. Pots were subirrigated as necessary.

The reflectant materlal was prepared by mixing $5 \mathrm{~g}$ of powdered kaolinite, $70 \mathrm{ml}$ of distilled water and $1 \mathrm{ml}$ of Tween-20 [Polyoxyethylene (20) sorbitan monolaurate, ICI America]. Plants recelving kaolinite treatment had adaxial surfaces of all leaves painted with the white substance. Application rate was about $225 \mathrm{mg}$ kaolinite per $\mathrm{dm}^{2}$ leaf area (ABOU-KHALED et al. 1970). Plants were treated with kaolinite after the expansion of the second trifoliolate leaves on November 4, and herbicldes were applied to the soll surface two days later.

There were 13 herbicide treatments: atrazine to soll ratio of $0.01,0.05,0.10,0.20,0.30,0.40 \mu \mathrm{g} / \mathrm{g}$, and picloram to so11 ratio of $0.001,0.003,0.005,0.007,0.01,0.03 \mu \mathrm{g} / \mathrm{g}$; and a control which contained no herbicide. Each of the above treatments consisted of 8 pots, 4 of which recelved reflectant treatment. A split plot design was used.

During the first 2 days following herbicide application, alr temperature and 1rradiance in the greenhouse were measured 7 times a day (between 0800 and 2000 solar t1me) at 2 hourly intervals. Also measured were leaf temperatures of plants that recelved 0.10 and $0.40 \mu \mathrm{g} / \mathrm{g}$ of atrazine; 0.0005 and $0.03 \mu \mathrm{g} / \mathrm{g}$ of plcloram; and the control. Alr temperature was measured with a mercury thermometer; and leaf temperature with copper-constantan thermocouples. Irradiance was measured $10 \mathrm{~cm}$ above the plants with an Eppley Pyranometer (Model PSP, Eppley Lab, Inc. U.S.A.). The effect of herbicide treatments on dry welght reduction of soybean plants was evaluated 10 days after herbicide application, on November 16 for kaolinite treated and untreated plants. Plants were cut at soll level and their dry welght was determined after drying at $90 \mathrm{C}$ for 4 days. A response curve was drawn for each herbicide, with and without kaolinite treatment, to determine the soll herbicide concentration required for $50 \%$ reduction in dry welght (GR50).

The effect of kaolinite treatment on transpiration was determined in a second experiment involving 8 pots ( 1 plant/pot) that recelved no herbicide treatment. Four of the plants were painted with kaolinite while the remaining four plants were not. Water loss from soll in the pots was prevented by sealing the soll-surfaces with black plastic sheets. Water loss was measured six times (every $2 \mathrm{~h}$ ) throughout the days of November 7 and 8 (0800 to 1800 solar time) with a top-loading balance. Leaf area was determined just before and 1mmediately after the transpiration study, using an electronic area meter (Model LI30) and an accessory transparent belt conveyor (Model LI 3050A/I) from Lambda Instr. Corp., Lincoln, Nebr., U.S.A. Inftlal leaf area measurements were made by marking the outline of Individual leaves of a plant on sheets of paper, exclsing the leaf outline, and measuring the area with the instrument. Final leaf area measurements were made on the leaves after removing them from the plants. The leaf area per plant was used to compute transpiration rates of each plant. 
Data were statistically analyzed and means were separated with Duncan's Multiple Range Test.

\section{RESULTS AND DISCUSSION}

The mean air temperature and mean Irradiance in the greenhouse on November 7 and 8 were $25.5 \mathrm{C}, 281 \mathrm{Wm}^{-2} ; 29.2 \mathrm{C}, 329 \mathrm{Wm}^{-2}$, respectively. Transpiration rates were higher for untreated than for the reflectant treated plants on both days and at each analysis time (Table 1). Transpiration was also higher for both treatments on November 8 when both mean alr temperature and irradiance were higher. Transpiration increased from 0800 to $1400 \mathrm{~h}$ solar time, and then decreased rapldiy, perhaps due to stomatal closure in response to water stress, or other diurnal environmental varlable. Transpiration was reduced an average of $15 \%$ by kaolinite treatment during the two days.

TABLE 1

Effect of kaolinite leaf reflectant treatment on the transpiration rate of 28 day old soybean leaves for 2 consecutive days in the greenhouse.

\begin{tabular}{|c|c|c|c|c|}
\hline \multirow[b]{2}{*}{$\begin{array}{l}\text { Solar } \\
\text { time }\end{array}$} & \multicolumn{4}{|c|}{$\begin{array}{l}\text { Transpiration Rate of Soybean Plants } \\
7 \text { Nov. } \\
\end{array}$} \\
\hline & $\begin{array}{l}\text { Kaolinite } \\
\text { treated }\end{array}$ & Untreated & $\begin{array}{c}\text { Kaolinite } \\
\text { treated }\end{array}$ & Untreated \\
\hline 0800 & $0.86 a *$ & $1.28 \mathrm{~b}$ & $2.19 a$ & $2.42 \mathrm{~b}$ \\
\hline 1000 & $1.25 a$ & $1.58 \mathrm{~b}$ & $3.17 \mathrm{a}$ & $3.47 \mathrm{~b}$ \\
\hline 1200 & $1.70 \mathrm{a}$ & $2.09 b$ & $3.29 \mathrm{a}$ & $3.88 b$ \\
\hline 1400 & $2.99 a$ & $3.28 \mathrm{~b}$ & $3.42 \mathrm{a}$ & $3.98 \mathrm{~b}$ \\
\hline 1600 & $0.94 a$ & $1.08 \mathrm{~b}$ & $1.23 a$ & $1.59 \mathrm{~b}$ \\
\hline 1800 & $1.04 a$ & $1.21 \mathrm{~b}$ & $1.10 \mathrm{a}$ & $1.39 \mathrm{~b}$ \\
\hline
\end{tabular}

* Means in rows under different dates followed by different letters are significantly different at 5\% level using Duncan's Multiple Range Test.

Mean leaf temperatures were ajso higher for non-reflectant treated as compared to reflectant treated soybeans (Table 2). Leaf temperatures were higher on November 8 than November 7 . These differences in leaf temperature undoubtedly explain the differences in transpiration rates between the two treatments. Soybean plants treated with atrazine or picloram exhibited higher leaf temperatures than the controls on both November 7 and 8 . Herbicide-treated plants which also received kaolinite treatment were generally associated with lower leaf temperatures than those that only recelved herbicide treatment (Table 2). 
TABLE 2

Leaf temperature of soybean leaves treated with koalinfte leaf reflectant treatment, atrazine, and picloram.

\begin{tabular}{|c|c|c|c|c|c|}
\hline \multirow[b]{2}{*}{ Herbictde } & \multirow[b]{2}{*}{$\begin{array}{l}\text { Rate } \\
\mu g / g\end{array}$} & \multicolumn{4}{|c|}{$\begin{array}{l}\text { Leaf Temperature of Soybean P1ants } \\
7 \text { Nov. } \\
\end{array}$} \\
\hline & & $\begin{array}{c}\text { Kaolinite } \\
\text { treated }\end{array}$ & Untreated & $\begin{array}{c}\text { Kaolinite } \\
\text { treated }\end{array}$ & Untreated \\
\hline Control & - & $24.4 a *$ & $25.5 b$ & $26.5 a$ & $27.7 c$ \\
\hline \multirow[t]{2}{*}{ Atrazine } & 0.10 & $25.4 \mathrm{~b}$ & $26.9 f$ & $27.2 b$ & $29.0 f$ \\
\hline & 0.40 & $26.0 \mathrm{c}$ & $27.8 \mathrm{~h}$ & 29.91 & $29.3 \mathrm{~g}$ \\
\hline \multirow[t]{2}{*}{ Picloram } & 0.0005 & $26.2 d$ & $27.3 \mathrm{~g}$ & $28.1 d$ & $29.7 \mathrm{~h}$ \\
\hline & 0.30 & $26.4 \mathrm{e}$ & $27.9 h$ & $28.4 \mathrm{e}$ & $30.1 \mathrm{j}$ \\
\hline
\end{tabular}

* Means pertaining to a particular date followed by a different letter are significantly different a 5\% level using Duncan's Multiple Range Test.

TABLE 3

Effect of atrazine concentration and kaolinite leaf reflectant treatment on soybean dry weight reduction.

\begin{tabular}{ccc}
\hline & \multicolumn{2}{c}{ Dry welght reduction } \\
\cline { 2 - 3 } Rate & Kaolinite treated & Untreated \\
\hline$\mu \mathrm{g} / \mathrm{g})$ & $--(\%$ reduction from contro1) & \\
0.01 & $19.7 \mathrm{a} *$ & $32.4 \mathrm{bcd}$ \\
0.05 & $22.4 \mathrm{ab}$ & $39.4 \mathrm{cdef}$ \\
0.10 & $29.9 \mathrm{abc}$ & $47.2 \mathrm{efg}$ \\
0.20 & $35.5 \mathrm{cde}$ & $53.5 \mathrm{ghi}$ \\
0.30 & $42.7 \mathrm{defg}$ & $59.1 \mathrm{hi}$ \\
0.40 & $50.8 \mathrm{fgh}$ & $64.6 \mathrm{i}$ \\
\hline
\end{tabular}

*Means followed by the same letter do not differ significantly at the 5\% leve1 using Duncan's Multiple Range Test.

Soybean dry weight was reduced less by atrazine treatment with reflectant than without at each level of atrazine (Table 3). The calculated $G_{50}$ for atrazine was 0.38 and $0.16 \mu \mathrm{g} / \mathrm{g}$ for reflectant treated and non-reflectant treated plants, respectively. Leaf reflectant treatment also reduced picloram injury to soybeans at each picloram rate (Table 4). The $\mathrm{GR}_{50}$ for picloram was $0.03 \mathrm{\mu g} / \mathrm{g}$ for the non-reflectant treated plants. GR 50 for the reflectant treated plants was greater than the highest concentration employed in this study.

It has been well established that the phytotoxicity of rootabsorbed herbicides increases with increased transpiration rate (MINSHALL 1954, OORSCHOT 1970). The increased albedo from the kaolinite leaf treatments caused a decrease in phytotoxicity in this research by decreasing leaf temperature and transpiration 
rate. If this relationship between crop albedo and herbicide phytotoxicity holds true under field conditions, it could be a factor in herbicide selectivity in crop plants. This could be tested with use of isolines that differ only in leaf color. Golden isolines of barley, for example, have been found to reflect 3.5 to $6 \%$ more solar radiation than normal green plants, with corresponding reduction of canopy temperature of 1 to $2 \mathrm{C}$ (AASE 1971, FERGUSON et a1. 1973). The relationship between crop albedo and phytotoxicity of root-absorbed herbicides merits further study as it can influence cholce of crop varieties/ cultivars in cases of probable crop injury due to herbicide persistence.

\section{TABLE 4}

Effect of picloram concentration and kaolinite leaf reflectant treatment on soybean dry weight reduction.

\begin{tabular}{lcc}
\hline & \multicolumn{2}{c}{ Dry weight reduction } \\
\cline { 2 - 3 } Rate & Kaolinite treated & Untreated \\
\hline$(\mu \mathrm{g} / \mathrm{g})$ & $2.6 \mathrm{a} *$ & $4.6 \mathrm{a}$ \\
0.001 & $14.6 \mathrm{~b}$ & $20.5 \mathrm{bc}$ \\
0.003 & $22.0 \mathrm{bcd}$ & $29.6 \mathrm{de}$ \\
0.005 & $26.8 \mathrm{cde}$ & $34.6 \mathrm{efg}$ \\
0.007 & $32.2 \mathrm{fg}$ & $41.5 \mathrm{~h}$ \\
0.010 & $37.8 \mathrm{gh}$ & 50.01 \\
0.030 & &
\end{tabular}

* Means followed by the same letter do not differ slgnificantly at the 5\% level using Duncan's Multiple Range Test.

\section{REFERENCES}

AASE, J.K: Agron: J. 63, 425 (1971). ABOU-KHALED, A., R.M. HAGEN, and D.C. DAVENPORT: Water Resour. Res. 6, $280(1970)$. AST̄TON, F.M: Weeds 13, 164 (1965).

BARADAS, M.W., B.L. BLAD, and N.J. ROSENBERG: Agron. J. 68,843 (1976).

DORAISWAMY, P.C., and N.J. ROSENBERG: Agron. J. 66, 224 (1974). FERGUSON, H., R.F. ESLICK, and J.K. AASE: Agron. J. 65, 425 (1973). FUCHS, J., G. STANHILL, and S. MORESHET: Agron. J. $6 \overline{8}, 865$ (1976). LEMEUR, R., and N.J. ROSENBERG: Agron. J. 68, 30 (1 $\overline{976})$. MINSHALL, W.H.: Can. J. Bot. 32, 795 (1954). OORSCHOT, J.L.P. VAN: Weed Res. 5, 84 (1965). OORSCHOT, J.L.P. VAN: Weed Res. 10 , 230 (1970). STANHILL G., S. MORESHET, and M. FUCHS: Agron. J. 68, 329 (1976). 